\title{
Reflexões sobre antropologia e liberdade política em Ludwig Feuerbach
}

\author{
Reflections on anthropology and political freedom in Ludwig \\ Feuerbach
}

Antônio Adriano de Meneses Bittencourt

adriano468@yahoo.com.br

(Universidade Federal do Ceará, Ceará, Brasil)

\begin{abstract}
Resumo: 0 artigo expõe o pensamento antropológico de Ludwig Feuerbach na dimensão da política, enfatizando que sua crítica à religião, para além da redução do objeto religioso à subjetividade, sustenta contornos políticos em favor da autodeterminação dos homens. Nesse contexto, reflete-se sobre o tema da liberdade e suas condições para que seja efetiva. Em articulação às ideias do filósofo, fazemos uma breve incursão na história evocando a crítica de José Carlos Mariátegui (1894-1930) quanto ao processo de abertura política no Peru, analisando a questão indígena enquanto marcada pela diferença entre o singular modo de viver desses povos frente aos desafios postos pela república, um dilema cujos pressupostos descortinamos a partir de Feuerbach e que persiste no debate político atual concernente à legitimidade das diferentes formas de organização social e política.
\end{abstract}

Palavras-chave: Feuerbach; Antropologia; Política; Mariátegui.
Abstract: The article exposes Ludwig Feuerbach's anthropological thought in the dimension of politics, emphasizing that his critique of religion, beyond the reduction of the religious object to subjectivity, supports political contours in favor of men's selfdetermination. In this context, we reflect on the theme of freedom and the conditions for its effectivity. In articulation with the philosopher's ideas, we make a brief incursion into history evoking the criticism of José Carlos Mariátegui (1894-1930) regarding the process of political opening in Peru, analyzing the indigenous issue as marked by the difference between the unique way of life of these peoples facing the challenges posed by the republic, a dilemma whose assumptions we unveiled from Feuerbach onwards and which persists in the current political debate concerning the legitimacy of different forms of social and political organization.

Keywords: Feuerbach; Anthropology; Politics; Mariátegui.

DOI: http://dx.doi.org/10.11606/issn.2318-9800.v26i3p27-41

\section{Introdução}

A obra de Feuerbach pode, a princípio, revelar muito mais ao pesquisador contemporâneo do que ele possa prever. Estamos certos disso, pois, lendo-a, podemos ter a sensação de estarmos diante de um pensador que reflete com sobriedade os problemas fundamentais da humanidade, se situando ao lado dos chamados filósofos "póstumos", na medida em que suas ideias cruzam os séculos. Dada sua obscuridade e assistematicidade, bem como certo ostracismo de parte da historiografia filosófica oficial, os escritos do filósofo foram pouco tomados a sério antes que fosse deles 
feito uma imagem vulgar e caricata. Até aí, podemos dizer que não se trata de alguma novidade, sendo frequente a adoção de tal prática entre os filósofos, dos quais Feuerbach também não figurará como "exceção à regra".

À parte isso, o propósito que nos motivara escrever esse artigo está, no entanto, em outro elemento. Refere-se à particularidade de seu pensamento antropológico em articulação a alguns excertos que nos levam a refletir acerca de seu pensamento político. Desde já, salientamos tratar-se de um assunto mais amplo, devendo, nos limites desse texto, ter sua apreciação apenas enquanto um esforço particular de nossa parte com vistas a descortinar novos rumos nas pesquisas sobre o filósofo. Feitas essas considerações, passemos à tarefa que nos colocamos.

\section{O homem integral}

Nos chama atenção, em primeiro lugar, o que Feuerbach compreende por homem integral. A descrição que seguirá referenciar-se-á através de um exemplo concreto sob a assinatura dos pressupostos de sua noção geral de homem, tal como a desenvolve em A essência do cristianismo (publicada em 1841), a saber, formado por três qualidades ou forças essenciais: afetos (coração), vontade e razão ${ }^{1}$. Nesta obra, Feuerbach investiga a religião cristã e conclui reduzindo-a ao homem no desejo de superar as contradições postas pela natureza. Os argumentos, na obra, se concentram em revelar o objeto da religião, Deus, como um ser construído pela subjetividade, revelando, assim, o prenúncio de uma era que porá em discussão o papel dos limites da religião no Estado. Ainda, em A essência, Feuerbach capta a dimensão do sofrimento humano que, diante da privação de uma existência plenamente satisfatória, abraça a fé em uma promessa de vida após a morte livre de toda carência e limitação, como nos diz a passagem logo abaixo:

\footnotetext{
1 Pouco se alude ao fato de Feuerbach ter caracterizado o ser humano de forma trinitária. Considerando a época, ainda que "turbulenta", em que veio à luz a publicação de $A$ essência do cristianismo (período em que residia em Bruckberg, pouco antes do Vormärz, quando a Alemanha se encontrava em grande efervescência intelectual e política, tecendo-se por todas as partes críticas cada vez mais severas à religião enquanto censor político), não é de todo explicitado que tal inspiração the tenha surgido por algum movimento particular do período. Porém, dada a "obsessão" que o tema da religião the provocara, pode nos parecer natural que Feuerbach tenha tomado certas categorias estruturantes da última como recurso alegórico que tipificam o ser total do homem. Sabe-se que a constituição tríplice está na história do pensamento de diferentes formas, por exemplo, na religião, pelo Cristianismo (Pai, Filho, Espírito Santo); a explicação das partes da alma na filosofia platônica (logistikon, thymoeides, epithymetikon); no ocultismo ou no misticismo, em relação às partes da alma segundo à cabala (nefesh, ruah e neshamah), etc. Um interessante estudo sobre os diferentes significados do número três associado a esses empregos encontramos comumente nos trabalhos de místicos e ocultistas. Aqui, destacamos a obra do ocultista francês Papus, Traité élémentaire de science occulte, de 1888 (com tradução para o português). Permanece, no entanto, incógnito se Feuerbach copia essa forma de classificação de algumas dessas tradições. Contudo, não nos parece como um todo estranho se considerarmos que sua filosofia pretende tornar concreto o que fora tomado como místico ou abstrato, reduzindo, assim, cada uma dessas forças ou disposições a partes constituintes da essência material do homem, portanto, físicas e naturais.
} 
Por isso a felicidade celestial não é de modo algum uma felicidade somente espiritual, mas da mesma forma também corporal, sensorial [...] "Lá a própria carência morrerá. Então serás verdadeiramente rico, quando de nada mais necessitares" (Agostinho. Serm.ad pop., p. 77, c.9). [...] é a existência em um corpo sem fardo, sem peso, sem fealdade, sem doença, sem mortalidade associado ao sentimento do mais elevado bem-estar corporal (Feuerbach, 2009a, p. 319-320).

Portanto, um dos primeiros fatores de aprisionamento do homem é a religião que o leva a incorporar uma condição supranaturalista marcada por um acentuado subjetivismo que nega a natureza por estar ela em contradição com a vontade do cristão. Um pouco mais tarde, em Princípios da filosofia do futuro, de 1843, Feuerbach passará à crítica aos modernos denunciando, em particular, o excessivo subjetivismo que molda as discussões no campo da metafísica e culmina em uma circularidade teórica que, nos mesmos termos do discurso teológico (que transforma em conceitos a experiência do religioso e, portanto, falseia o fundamento em que se situa a religião), agrilhoa a possibilidade da diferença sensível para a explicação e eventual superação dos problemas que afligem o ser humano. ${ }^{2} \mathrm{E}$ o sofrimento é, para ele, distinto nos homens. Naturalmente que a dor física não pode ser negada aos demais animais, mas apenas o homem, por possuir a capacidade de se elevar à religião, demonstra já uma inigualável condição de existência que o qualifica como carente espiritualmente, sendo o sofrimento uma falta em dupla condição, física e espiritual. Convém, assim, antes de considerarmos sua explicação acerca do homem integral, avaliar o que o filósofo nos diz sobre a diferença entre aquele e os demais animais.

O homem de nenhum modo se distingue do animal só pelo pensamento. Pelo contrário, o seu ser total é que o distingue do animal. Sem dúvida, aquele que não pensa não é homem algum; não é porque o pensar seja a causa do ser humano, mas unicamente porque é uma consequência e uma propriedade necessária do mesmo ser humano. Por conseguinte, não precisamos aqui de sair do domínio da sensibilidade para reconhecer no homem um ser superior aos animais. 0 homem não é um ser particular como o animal, mas um ser universal, por conseguinte, não é um ser limitado e cativo, mas um ser ilimitado e livre; com efeito, a universalidade, a ilimitação e a liberdade são inseparáveis. E esta liberdade também não reside numa faculdade particular, na vontade, da mesma maneira que esta universalidade não se situa numa disposição particular da faculdade de pensar, na razão - esta liberdade, esta universalidade estende-se ao seu ser total. Sem dúvida, os sentidos animais são mais agudos do que os humanos, mas apenas em relação a coisas determinadas, necessariamente conexas com as necessidades do animal, e são mais agudos justamente por causa dessa determinação, desta restrição exclusiva a algo de determinado. 0 homem não

2 A sensorialidade (Sinnlichkeit), ou melhor, a diferença sensível, possui a condição de exortar todos os fantasmas da nebulosidade teórica em Feuerbach. Como analogia, o filósofo expõe que seu pensamento pode ser simbolizado pela elipse, com dois focos através dos quais o discurso se engendra e se qualifica (a relação entre um Eu com um Tu, concreta e determinada), em contraste com o hegelianismo, caracterizado pela circularidade propiciada pela diferença abstrata no interior da Doutrina do Ser, portanto, originada do espírito em direção a si próprio, isto é, de um Eu originalmente abstrato a um Tu carente de determinações sensíveis. 
tem o faro de um cão de caça, de um corvo; mas apenas porque o seu olfacto pode abranger todas as espécies de odores, pelo que é um sentido livre e indiferente a respeito de odores particulares. Mas onde um sentido se eleva acima dos limites da particularidade e da sua vinculação à necessidade, eleva-se a uma significação e dignidade autónomas, teóricas: sentido universal é o entendimento, sensibilidade universal é espiritualidade. Mesmo os sentidos mais baixos, o olfacto e o gosto, se elevam no homem a actos espirituais e científicos (Feuerbach, 2009b, p. 70-71, grifo nosso). ${ }^{3}$

Os animais, ainda que reconheçamos suas façanhas e argutas disposições, deixam-se determinar pela natureza. Assim, desvela-se ao homem um destino especial, determinado e diferente em relação aos outros animais. 0 "sentimento do universal", a que o autor se refere, define, assim, um modo particular de se situar no mundo, a saída de si em direção ao outro, posto que o outro é aquele através do qual eu sou e me compreendo como tal, a quem sou capaz de me doar integralmente. Essa entrega ao outro é semelhante à morte. ${ }^{4}$ Diante disso, atentemos agora ao que Feuerbach compreende como homem em sentido pleno.

A arte, a religião, a filosofia ou a ciência são apenas as manifestações ou revelações do ser humano verdadeiro. Homem perfeito e verdadeiro é apenas quem possui o sentido estético ou artístico, religioso ou moral, filosófico ou cientifico - homem em geral somente é aquele que nada de essencialmente humano exclui de si mesmo. Homo sum, humani nihil a me alienum puto - esta frase, tomada na sua significação mais universal e mais elevada, é a divisa do novo filósofo (Feuerbach, 2009b, p. 72, grifo nosso).

Assim, o homem integral ou pleno é aquele em que nada the é subtraído na qualidade de homem, na expressão íntima de sua essência. Na comparação com os demais animais, "sobram-lhe" atributos, através dos quais permite-se a passagem do simples ao complexo, do isolado ao integrado, do uno ao múltiplo. Trouxemos essa passagem, no entanto, para fazer a seguinte consideração: se o homem verdadeiro,

3 É importante ressaltar que a noção de superioridade aludida na citação, ainda que expresse simplesmente a razão como uma qualidade específica do homem em relação aos demais seres, posteriormente, irá se diluir em uma concepção de natureza horizontalizada, advogando, Feuerbach, contra o suposto direito do ser humano sobre a natureza em detrimento dos outros animais, o que coloca Feuerbach, em nossa ótica, na vanguarda dos desdobramentos que culminarão mais tarde nas diversas correntes do ecologismo.

4 A ênfase na presença do outro é um dos pontos centrais da antropologia feuerbachiana e que se manterá ao longo de seus escritos. Em Pensamentos sobre morte e imortalidade (Gedanken über Tod und Unsterblichkeit), Feuerbach, ainda imbuído do espírito místico que anima seu pensamento de juventude, explica que a morte é, em última instância um "ato de amor", pois é a passagem do finito (homem) para o infinito (Deus). Ainda que a ideia de Deus seja postergada nos escritos ulteriores, mantêm-se, contudo, a compreensão de que o amor é a aspiração mais forte que possibilita a exteriorização do homem, culminando também em um tipo de morte para o acolhimento do outro. Em sociedade, o homem (finito) experimentaria, assim, "várias mortes", à medida em que se aperfeiçoa constantemente no relacionamento com seus pares, tornando o gênero (que assume a infinitude no lugar de Deus) mais rico e diversificado quanto mais os homens se permitem uma "filantropia universal". 
é, assim, aquele que não deixa de fora o que the é próprio, em consonância ao que é expresso pela frase em latim (extraída de Terêncio) que acompanha o texto citado logo acima, devemos compreender, assim, entre os demais aspectos constituintes da essência total do homem, a dimensão religiosa como igualmente dignitária ao lado das outras duas (estética, científica).

\section{Crítica à religião como atitude política}

Antes de tudo, é importante salientar um fato: como muitas outras "pontas soltas" de sua assistemática filosofia, Feuerbach não deixa claro suas inclinações políticas. Comungava de uma defesa à república, mas o que lemos de seu republicanismo, em particular, em Necessidade de uma reforma da filosofia, de 1842, é uma concepção generalizada e otimista quanto à ideia de um governo composto por diferentes cabeças, em um anseio de que, gradualmente, os homens se emancipassem politicamente "preenchendo" o largo espaço deixado ao arbítrio religioso por parte das repúblicas onde aquelas tomavam as rédeas da liberdade alheia. Desse modo, salientamos que suas preocupações políticas não se dissociam da discussão acerca dos limites da religião. Porém, como esperamos ficar mais claro no decorrer do texto, existem ao menos duas maneiras de se interpretar o tema da religião em Feuerbach: a religião enquanto fenômeno relativo à liberdade de fazer a si e a natureza como objeto distinto e como instrumento oficial de controle das liberdades. É acerca do primeiro tipo que encontramos elementos para se pensar o tema da liberdade nos limites da política segundo Feuerbach.

De fato, as obras do filósofo expõem mais acentuadamente os arbítrios e abusos cometidos pela religião em nome da defesa de seus princípios. Contudo, enquanto considerada de modo singular, a religião é uma atividade livre do espírito humano, ainda que Feuerbach a compreenda como propiciadora de uma relação obscura do homem consigo. Assim, cremos que, para além de tais considerações, há um outro (e mais importante) motivo por trás de sua crítica. Observemos o seguinte relato:

Interessa-me acima de tudo, e sempre me interessou, iluminar a obscura essência da religião com a luz da razão, para que finalmente os homens parem de ser explorados, para que deixem de ser joguetes de todos aqueles poderes inimigos da humanidade que, como sempre, servem-se até hoje da nebulosidade da religião para a opressão do homem (Feuerbach, 2009c, p. 35).

Portanto, distingue-se em seus argumentos uma meta, um objetivo, a saber, libertar o homem do jugo opressor daqueles que se valem do discurso religioso para realizar seus desígnios sobre a vontade dos demais. Vemos, dessa forma, uma atitude, por assim dizer, política por parte do autor, que não se conforma com os abusos cometidos pelo uso arbitrário a que está sujeita a religião. Mas estaria 
apenas a religião condenada a uma tal ressalva? Não estariam, pois, a filosofia e a teoria, mesmo sob as mais belas aspirações, sujeitas a incorrer em expedientes de semelhantes abusos e opressões? No tocante à política, Feuerbach não se dedicará a análises aprofundadas, conservando, para seus detratores, a imagem de um pensador pouco consciente da situação real em que vivem os homens. De fato, o filósofo não tomará partido no que toca a um tipo específico de governo, como lemos no trecho seguinte:

Já Aristóteles diz em sua Política [...] que não só devemos conhecer a melhor legislação, mas também saber para quais homens ela convém, porque até a mais excelente não convém a todos. Por isso, quando se me constrói, sob o ponto de vista histórico [...] a monarquia constitucional [...] como única forma de governo que nos convém [...] eu concordo plenamente. Mas quando se me demonstra, sem se tomar em conta espaço e tempo [...] a monarquia como a única forma de governo racional, então, eu protesto (Feuerbach, 2009c, p. 374, grifo nosso).

Claramente, a maior parte das críticas de Feuerbach se dirige ao Estado cristão, que oprime aqueles que enxergam suas contradições e lutam pelo fim de seu domínio arbitrário, mas a essência do argumento do excerto supracitado pode servir a qualquer governo que utilize a retórica autoritária para fins de controle e punição de seus dissidentes. Porém, em ilação ao texto citado logo acima, cabe-nos alguns questionamentos: o que dizer das formas de governo que, ainda que assentadas na história, irrompem com ganas de obter a todo esforço o domínio, sem recusar mesmo o uso da violência? Seria suficiente para a política estar ela radicada na historicidade? Não teriam os homens também uma história? Não estaria a história também subordinada à subjetividade? Esses questionamentos apontam para o que trataremos no capítulo adiante acerca da relação entre liberdade e individualidade.

Feuerbach não deixa claro suas inclinações políticas. Comungava de uma defesa à república, mas o que lemos de seu republicanismo, em particular em sua Necessidade de uma reforma da filosofia, de 1842, é mais uma concepção generalizada e otimista quanto à ideia de um governo composto por diferentes cabeças, em um anseio de que, gradualmente, os homens se emancipassem politicamente em detrimento do excessivo espaço deixado ao arbítrio religioso por parte das repúblicas onde aquelas tomavam as rédeas da liberdade alheia.

Ademais, ainda que a religião constitua um perigoso e abstruso meio de dispor das liberdades, segundo Feuerbach, não decorre que ela seja abolida. A liberdade para tomar a si ou a natureza de forma mistificada é fruto também do homem integral. Segundo Feuerbach (2009b, p. 205), “Eu não destruo a religião [...] nem o ímpeto de objetivar e personificar o próprio íntimo”. A crítica de Feuerbach parece ser suficientemente clara ao apontar que não é a liberdade de pensamento que provoca obstáculos à emancipação do homem; ao contrário, é justamente quando 
se encerra no Estado o direito de julgar as outras liberdades por meio de um poder oficial sob princípios que suprimem do homem sua liberdade de pensar. Que se ponha, pois, nos termos de uma compreensão solidária consigo a crítica do filósofo: Feuerbach é ciente de que a imaginação e a fantasia fazem parte da vida humana, porém, na política, podem mais facilmente assumir o espectro do arbitrário quando ali se arvoram. Ao que indica, cabia a Feuerbach, antes de assumir um lugar entre os teóricos da política de seu tempo, propondo caminhos e soluções práticas nesse campo, denunciar os perigos que cercam a atividade política mesmo que sob as mais belas aspirações, tornando-se irrelevante que se circunscreva sob os auspícios do laicismo ou do ateísmo. Em outra passagem, Feuerbach (2009c, p. 394) nos diz "Em sentido prático é o individualismo um socialismo, não, porém, no sentido francês que é um socialismo que tira a liberdade ou a individualidade, o que dá na mesma, sendo essa última apenas uma expressão mais abstrata”.

\section{Liberdade, individualidade e felicidade}

Com base na citação logo acima, enxergamos um elemento radicalmente atual no pensamento de Feuerbach, a saber, a aproximação entre liberdade e individualidade. Se a política se dá à revelia dessa relação, perde seu fundamento, sua qualidade efetivamente política, isto é, compreendida como um esforço de muitos e diferentes indivíduos que, unificados pelo intuito de resolver questões essenciais da vida, entregam-se, como num ato voluntário (e por que não dizer, de amor?), em benefício de todos. A política real, em Feuerbach, é animada pelo espírito do altruísmo, ainda que se busque na individualidade o melhor para si. 0 egoísmo, ${ }^{5}$ na política, acaba por favorecer a todos, já que, na busca para uma melhor condição de vida, o homem é forçado ao encontro do outro e, assim, a reunião dos homens eleva o espírito da humanidade, desenvolvendo-se e enriquecendo-se a partir da multiplicidade de trocas entre os homens no Estado.

No Estado, as forças do homem separam-se e desenvolvem-se para, através desta separação e da sua reunificação, constituírem um ser infinito; muitos homens, muitas forças, constituem uma só força. O Estado é a soma de todas as realidades, o Estado é a providência do homem. No Estado, os homens representam-se e completam-se uns aos outros - o que eu não posso ou sei, outro o pode. Não existo para mim, entregue ao acaso da força da natureza; outros existem para mim, sou abraçado por um círculo universal, sou membro de um todo. O Estado [verdadeiro] é o homem ilimitado, infinito, verdadeiro, completo, divino. Só o Estado é o homem - o Estado é o homem

\footnotetext{
5 Feuerbach distingue duas formas de egoísmo em suas Preleções sobre a essência da religião, de 1848, um natural, condicionante de todo esforço do homem em direção a continuar existindo, e outro de aspecto moral. Não é preciso salientar por qual dos dois o filósofo advoga, dado o seu repúdio ao moralismo arbitrário que redimensiona o homem a subserviência cega. Além disso, em consonância ao que afirmamos na nota quatro desse artigo, o aspecto moral nos distingue negativamente em muitas coisas em relação aos animais, sobretudo, quando se toma o homem como um ser acima do restante da Natureza.
} 
que a si mesmo se determina, o homem que se refere a si próprio, o homem absoluto (Feuerbach, 2008, p. 6).

Porém, a noção de liberdade como sinônimo de individualidade tornase problemática na política porque nessa reside o esforço de uma "supravisão" acerca do homem, tomando-o não em sua concretude e determinidade, mas em sua expressão genérica e universal. ${ }^{6}$ Recuperar a dimensão sensível do homem, através do reconhecimento do outro como fundamental, é a tarefa do pensamento antropológico de Feuerbach, o que, por si, já é um ensejo a uma política centrada nos afetos, dado que, de um modo geral, a saída do homem em direção ao outro está não apenas determinada por condições materiais, mas, de modo igual, por valores espirituais e estéticos. Para além de um sistema mecânico de forças, como o quis Hobbes, o Estado, em Feuerbach, é mais do que o agrupamento cego de átomos, mas uma livre associação que se estabelece pelos diversos elementos que engendram a subjetividade, que, tal como na explicação do amor como sendo uma forma de "morte", pois é entrega deliberada de si, acolhe o desejo da permanente continuidade agora não mais de um, mas de toda a humanidade.

Nesse contexto, a liberdade torna-se um fator preponderante para a emancipação, dado que, sendo individualidade, ela traz de cada um para todos uma riqueza singular, uma contribuição específica que qualifica as relações descortinando um novo olhar sobre a humanidade, sobre seus modos de agir e pensar. Contudo, a liberdade, por si, não é suficiente. Tomada como simples palavra, desraigada das condições de existência, é supérflua. O homem quer ser, além de livre, feliz, pois, qual a razão de ser livre sem se poder ser feliz? Ainda: quem pode nos prover a felicidade? A isso, Feuerbach (1997, p.28) responde: “A felicidade varia de acordo com o país, as pessoas, o tipo de homem". Ser feliz, portanto, é uma condição também única e particular de cada povo, exigindo que qualquer argumento que envolva a garantia de liberdade deve incluir a felicidade em restrita observância aos costumes daquele.

Cada impulso insatisfeito, cada desejo não satisfeito, cada desconforto, cada sentimento de privação, cada perda, é uma deficiência ou uma negação, que desperta a perturbação do [...] instinto de felicidade, inato em cada ser vivo e senciente [...]. "Vontade sem liberdade é uma palavra vazia", diz Hegel. Mas uma palavra vazia e sem sentido é antes de tudo liberdade sem felicidade [...] Onde o mal não é mais percebido como um mal, nem a opressão dos despotismos, de qualquer tipo, como opressão, também a liberdade do mal e a opressão não é mais percebida e desejada como felicidade; mas quando um ser cessa de desejar a felicidade, cessa de desejar em sentido absoluto, cai à mercê da estupidez (Feuerbach, 1997, p. 13-14, grifo nosso).

6 Ver sobre isso a noção de humanidade, posta em dúvida pelo escritor e ambientalista Ailton Krenak (2019) como "pensada" de uma perspectiva que não inclui o modo de vida particular dos povos indígenas. 
O instinto de felicidade, como expõe o filósofo, nada mais é do que aquilo que torna a vida do homem digna de ser vivida. Portanto, sem arte, sem filosofia, mas também sem religião, estaria o homem amputado, incompleto, forçado a viver um contexto a contragosto, desanimado e abatido. A história nos cerca de exemplos que, sob a promessa de se elevar a dignidade humana, humilha-se o outro, desqualifica-se sua origem e identidade, cometendo-se os maiores abusos e atos desumanos. Como visto no excerto supracitado, Feuerbach está cônscio das dificuldades surgidas ao se tomar a liberdade de uma forma meramente abstrata, desraigada das condições concretas que definem as características de um povo, pois, estando ela em estreita ligação à felicidade, seria um total arbítrio exigir ao homem ser feliz de um modo diferente em que ele possa experienciar esse sentimento. Quanto a isso, nos diz Chagas:

a vontade real é sempre apenas a vontade de uma essência determinada; querer quer dizer querer sempre algo determinado, e querer algo pressupõe ser algo. Aquele, que quer, então, não só quer, mas ele quer sempre algo [...] Já que a vontade pressupõe o ser, o homem deve, então, ser pela sua vontade, o que ele é apenas das condições do seu ser, de sua natureza (Chagas, 2016, p. 22).

Desse modo, não basta apenas que a liberdade seja acompanhada da ideia de felicidade, mas que essa última esteja unida ao modo particular de cada povo, pois, como diz Feuerbach, a felicidade se distingue entre os homens, e, sendo ela determinada pelas condições subjetivas de fruição com a natureza e com o outro, não poderia ser definida por uma agenda externa, como uma promessa ou compromisso político que estabelecesse padrões usuais que servissem de "parâmetros" da felicidade. ${ }^{7}$

Assim, se tomarmos a felicidade como apanágio da liberdade, qualquer forma de governo que a preconize não pode ser subtraída por uma outra, ainda que se outorgue melhor, se naquela residir todo o modo de vida de um povo, um equívoco mostrado na prática pelos países do bloco socialista no século vinte, que, para ficar apenas no que diz respeito à religiosidade, ao invés de instituir uma proposta que favorecesse o sentimento ecumênico, tratando como assunto privativo ${ }^{8}$, a massacrou e oprimiu, exterminando alguns de seus representantes, forçando a natureza humana a amoldar-se aos desígnios do programa de governo.

\footnotetext{
7 É curioso que a noção "felicidade" hoje seja uma "variável” em pesquisas qualitativas sobre uma determinada região geográfica (definida através de fatores como baixo índice de violência, longevidade da população, etc.). Cabe ressaltar que além de tais pesquisas não serem tidas como científicas, é uma apropriação muito restrita do termo, que, naturalmente, está longe de abranger o que se depreende por felicidade no interior desse artigo.
}

8 Ver Lênin, $O$ socialismo e a religião (Lênin, 1977). 


\section{Deve a religião ser abolida pela política?}

Vê-se a razão pela qual Feuerbach se distanciou das ideias políticas de seu tempo. Sua crítica à religião é apenas uma faceta de uma crítica mais ampla dos desvios do poder político. Especificamente no tocante à religião, sua tarefa é trazer à luz os elementos subjetivos que determinam a fé, o que não pode ser confundido com uma atitude político-ideológica que se autorize a determinar aquilo em que os homens devem crer. Sua obra aponta os elementos e bases subjetivas da fé sem que com isso se criminalize a própria. É o que lemos na seguinte passagem da Ética:

Como em minha Essência da religião minha tarefa não é demonstrar que não existe deus, e certamente que nem mesmo que não exista um, então aqui minha tarefa não é demonstrar que o homem não tem a chamada liberdade de vontade, mas certamente que nem mesmo a tenha. Como lá eu apenas investigo as razões que determinam a fé do homem em Deus, então aqui minha tarefa, ou pelo menos minha principal tarefa, foi apenas traçar e representar as razões que determinam o homem ser livre (Feuerbach, 1997, p. 94-95). ${ }^{9}$

Parece-nos, assim, ter Feuerbach uma postura muito mais madura e consciente do que o relato de Engels nos sugere, afirmando: “Onde se revela o verdadeiro idealismo de Feuerbach é em sua filosofia da religião e em sua ética. Feuerbach não pretende, de forma alguma, suprimir a religião, o que deseja é completá-la. A própria filosofia deve converter-se em religião" (Engels, 2008). ${ }^{10}$ Não é retirar coisa alguma do ser humano, mas, diferentemente, pô-lo em evidência em totalidade, aclarando-lhe aquilo que retira seu direito de pensar e agir em conformidade com o que julga melhor para si, seja na religião ou na política, para que não se justifique os abusos e injustiças a preço de uma ideia que se queira incontestável.

Se Feuerbach fosse favorável à abolição da religião, como se justificaria sua

9 Muitas passagens do autor nos levam a considerar que o mesmo estaria menos comprometido com um ateísmo "forte" do que com a crítica à exposição tendenciosa e frágil de teólogos e filósofos em favor da existência de Deus. Não obstante de que, para Feuerbach, o conceito de Deus seja o universal tomado como uma essência autônoma, ele, tal como no suposto diálogo entre Napoleão e Laplace (onde o último revelaria que prescindia da ideia de Deus em sua hipótese da mecânica celeste), situa-se em um naturalismo que põe limites ao homem quanto a certas questões (sugerindo aí uma investigação também da linguagem), não apenas de natureza religiosa, mas também teórico-científicas (Feuerbach admite que o universo não tem começo e nem fim, o que contraria a pesquisa cosmológica nos dias de hoje), sejam elas plausíveis ou não, mas que em absolutamente nada favoreciam à emancipação da humanidade (a hipótese de Deus seria até mesmo um obstáculo ao progresso dado que encerraria qualquer investigação).

10 Concorda com nossa interpretação, apoiada em textos do próprio Feuerbach, que não há a pretensão de sua parte em destruir a religião. Contudo, a afirmação de que ele teria o interesse em completá-la, se com essa expressão Engels estaria afirmando que Feuerbach deseja fazer da religião uma espécie de "filosofia comum", não podemos encontrar uma justificativa para tal, pois, a nós, parece evidente que o último compreende a religião e a filosofia como atividades distintas e inconciliáveis, dado que a primeira tem sua origem no sentimento de dependência e na esperança, e a segunda é uma atividade teórica e livre que se choca com a forma antropomórfica de representação da figura da divindade pelo religioso. 
defesa pela liberdade, uma vez que está relacionada à felicidade a nível individual? Como pode o homem ser livre deixando de ser homem em sentido integral? Como desprezar, por exemplo, o sentimento íntimo do fiel em relação à sua fé? Teria Engels, assim como Marx, "esquecido" que o homem possui vontade e coração, ${ }^{11}$ uma relação sensível consigo e com o mundo? O fato é que o que se viu foi justamente a "entronização" de uma única faceta do humano, a saber, a razão, uma crença que só os filósofos (aqui, entre aqueles tomados por Feuerbach enquanto afeitos a uma imagem abstrata de homem) podiam crer, uma razão desvinculada do sentir, da vivência prática, longe do coração do homem real. 0 perigo, portanto, da racionalidade transformar-se em um algoz no que toca a liberdade é latente, dado a razão, por si, também pode ser dada aos delírios, como Feuerbach escreve a respeito da filosofia de Hegel. Por isso, o termo “razão", aqui, encarna-se na vivência prática dos seres, devendo, ela, estar também sujeita à história e não sujeitá-la. Quanto a isso, citamos Serrão:

O desenvolvimento sucessivo das categorias de Descartes a Hegel - da subjetividade pensante à subjetividade prática e ao sujeito absoluto - conduziu à elaboração gradual e, finalmente, à reposição de uma racionalidade supra e extramundana, isenta de determinações empíricas; colocada acima do mundo, como instauradora do conhecimento científico e filosófico e da ordem moral; acima dos fenômenos como fundamento da sua legalidade; em suma, a uma outra figura da transcendência (Serrão, 1999, p. 84).

\section{O dilema entre o particular e universal: Peru, um caso pontual}

Com base nisso, chegamos à seguinte questão: Como conciliar o particular, isto é, o individual, e o universal na política? Que alternativa de governo pode favorecer um resultado mais próximo de um contentamento geral? Parece que, ao acompanharmos a estreita relação que Feuerbach faz entre a liberdade e a felicidade, descortinamos, em revelia às suas afirmações, um paradoxo político onde o sujeito deve se fazer objeto de um outro para se afirmar enquanto tal.

Desse modo, o acento de Feuerbach quanto à inviolabilidade do direito de

11 Sobre esse ponto, vale aludirmos à obra Reflexões sobre as causas da liberdade e da opressão social, de Simone Weil. Entre elogios e críticas a Marx, a filósofa francesa destaca que o último foi deveras "ingênuo" em conceber uma revolução operária na esteira dos avanços da razão no ocidente, que acabaram por sufocar o homem e restringi-lo a uma mera ferramenta na engrenagem da economia. Assim, Weil aponta que Marx não trouxe em seu programa um projeto que contemplasse a formação do homem em sua totalidade, abandonando-o nas "mãos do progresso", o que foi levado a cabo não só pelas potências capitalistas do Ocidente, mas, e principalmente, pelos países do bloco comunista. A transformação do homem em massa de mão-de-obra atingiu extremos a ponto de se moldar uma imagem do mesmo, para usar um termo de Marcuse, unidimensional, carente e empobrecida. Não convém aqui abranger a totalidade de implicações que uma visão restrita da subjetividade humana trouxe, mas fomentar o debate provendo indícios suficientemente claros que favoreçam à pesquisa sobre o tema da liberdade na obra de Feuerbach, sem dúvida, conduzindo a caminhos bem diversos daqueles tomados por programas de governo que se apropriaram das teses de Marx. 
autodeterminação em consonância ao instinto de felicidade nos conduz a traçar aqui um justo, porém, limitado paralelo entre as aspirações políticas do pensador alemão e a história da consolidação da república, celebrada praticamente em uníssono como modelo singular na defesa contra os abusos de um poder centralizador e despótico, segundo aspiravam os intelectuais modernos. Nos concentraremos em uma análise breve acerca da república peruana, em 1821. Vamos a isso.

Um dos mais significativos estudos sobre esse período da história da América encontra-se na obra de José Carlos Mariátegui, pensador de verve marxiana cujo trabalho, entre outros temas, ressalta as diferenças dos povos nativos da América (sua cultura, política, economia, etc.) em relação ao modelo político-econômico do ocidente europeu. Para Mariátegui, um dos mais danosos prejuízos à população indígena fora a total desintegração da identidade do nativo através das leis da república que, ao contrário de garantir o direito de todos, manteve um sistema regido por caudilhos empurrando tais populações ao desespero e à exclusão.

Em paralelo, de acordo com esse autor, a noção de progresso nos termos da república peruana, oriunda do jacobinismo (que, de modo pejorativo, nada mais significa que uma forma demagógico-abstrata de defender a liberdade dos povos) manteria intocada o problema do nativo peruano, uma vez que nem mesmo o voto poderia servir de qualquer tipo de garantia para a melhoria de sua situação. Desse modo, abandonados à própria sorte, a ruína de toda uma tradição de experiências que formaram a identidade dos povos nativos fora exterminada em prol de um modelo de organização político-social estranho à sua formação, sob a bandeira da emancipação. Nem mesmo o voto os livraria desse destino. De acordo com Mariátegui

As massas rurais, as comunidades indígenas, em todo caso, se manteriam estranhas ao voto e a seus resultados [...] os organismos e os poderes que se criaram por "elegibilidade", porém sem seu voto, não poderiam e nem saberiam nunca fazer-lhes justiça (Mariátegui, 2003, p. 5).

Segundo o autor, a república é o maior inimigo do indígena porque não pode compreendê-lo. A população indígena possui sua essência ligada à terra e à comunidade. Como diz Mariátegui (2010, p.2) "A terra sempre fora toda a alegria do índio". São povos que formaram sua identidade no acúmulo de práticas e vivências na própria natureza e de modo coletivo. Essas vivências são indissociáveis de seu instinto de felicidade, isto é, daquilo que compreendem como mais digno a ser experienciado. Portanto, negar-lhes isto é negar-lhes a própria vida, pois, diferente do restante dos animais, enquanto ser que fantasia e projeta, a complexidade do ser humano reside em não se limitar à natureza, mas tornar seu modo de viver único com base em sua essência singular e diversa.

Se a individualidade é apenas um termo abstrato para liberdade como nos diz Feuerbach, e sendo a liberdade, como no exemplo que trazemos, uma garantia 
dada por um instrumento estranho (voto) aos costumes do nativo peruano, logo, em articulação à "regra" que nem a mais excelente das legislações convém a todos, considera-se que um tal exemplo jamais poderia estar de acordo com uma concepção razoável de governo, dado que o que é tomado como melhor ou superior (república) é imposto em flagrante arbítrio contra a natureza das convenções que regem e determinam a singularidade das populações indígenas no caso aqui analisado.

O homem do Ocidente, afeito ao individualismo, à abstração, ao universal, estaria em contraposição ao indígena, coletivista, sensorial e regionalista. Apresentam-se, assim, duas maneiras distintas de pensar a relação do homem com o mundo, duas formas de organização política e social divergentes em seus auspícios. Excetuando-se os casos em que os excessos põem em risco a integridade humana, nada há que se condene, na prática, em ambas as formas. Feuerbach bem o sabia quando, em suas Preleções sobre a essência da religião, contrapondo as religiões da natureza às religiões do espírito, ressalta que embora as primeiras não fossem livres de superstições, como a religião em geral, elas conduzem o homem a tomar como sagrada a própria natureza e, assim, reconhecer sua necessidade e importância para a vida. Como não deixar de ver certa beleza poética em um povo que eleva ao nível de uma divindade uma árvore ou um lago? Quisera a humanidade pudesse hoje ter se elevado a uma tal saúde espiritual e não veríamos a ruína da natureza sob os clamores do progresso!

A analogia entre religião e governo no parágrafo anterior é uma das muitas formas de se estabelecer relações entre diferentes instâncias a partir do pensamento feuerbachiano. Assim como no embate entre cristãos e pagãos, onde os últimos foram execrados por tomarem a diversidade natural como sagrada em contraste a uma visão que reconhecia a supremacia do ser humano frente às demais criaturas, a política pode se converter em visões que impinjam um modelo cristalizado de poder que se volte contra a multiplicidade característica dos povos, algo que, como sabemos, constituiu o traço marcante do avanço das potências ocidentais europeias frente a outros continentes.

\section{Conclusão}

Abordamos aqui o pensamento de Feuerbach sob uma perspectiva bastante particular, discorrendo sobre o tema da liberdade nos limites de sua antropologia filosófica, dando passagem para algumas incursões em questões políticas que acreditamos tocarem diretamente ao tema. Quisemos, nesse artigo, apresentar sua filosofia como abstraída de um projeto político definido, pois o tema da liberdade transcende a qualquer matéria particular, sendo, portanto, a questão da emancipação humana, antes, um compromisso firme com o primado da soberania e 
da autodeterminação.

Em consonância a isso, mostramos, através do breve exemplo da república peruana, os prejuízos ao modo de vida dos povos nativos, tal como esse fato nos é relatado pela obra de Mariátegui, forçando-nos observar por meio de um exemplo real os problemas da aplicação de um modelo de liberdade em sentido político que se pretenda universal, ainda que embasado em preceitos que se autorizem "elevar a natureza dos homens", pois, há sempre o risco de se fazer impor uma forma de governo que não esteja de acordo com a organização e costumes de um povo. Para Mariátegui, a república, saudada na modernidade como modelo pour l'excellence de emancipação política, resultou no despacho de uma massa de homens desorientados, cuja violência e o genocídio que sua memória sofrera séculos antes tornou em migalhas o lastro que os reconduziria ao sentido pleno da vida.

Nesse texto, ao tratarmos do tema da liberdade, avaliamos que, no que toca a política, para Feuerbach, é indiferente o emprego de qualquer forma de governo, pois o filósofo estaria interessado nos elementos subjetivos da dominação e exploração do homem, combatendo tanto os extremismos da razão como da fé, porquanto compreende não existir razões absolutas e universais que concedam, por si, o direito a dispor da liberdade alheia, dada que essa descansa no particular. Portanto, em extrema concordância com seu pensamento, não são as ideias que devem guiar o homem a um destino saudável, mas, ao contrário, são os homens que devem guiar as ideias abdicando delas sempre que sentirem que estão sendo tiranizados.

Referências

Aristóteles. (1998). Política. Pontinha: Vega.

Chagas, E. F. (2016). A Vontade é livre? Natureza e Ética em Ludwig Feuerbach. Revista Dialectus, 6, 1-34.

Engels, F. (2008). Ludwig Feuerbach e o fim da filosofia clássica alemã. Recuperado em 10 abril, 2021, de http://www.escolapcdob.org.br/file.php/1/materia is/pagina_inicial/Biblioteca/54_ENGELS_Ludwig_Feuerbach.pdf.

Feuerbach, L. (1993). Pensamientos sobre muerte e inmmortalidad. Madrid: Alianza Editorial.

Feuerbach, L. (1997). Ética e Felicità. Milano: Guerini e Associati.

Feuerbach, L. (2008). Necessidade de uma reforma da filosofia. Recuperado em 06 setembro, 2020, de http://www.lusosofia.net/textos/feuerbach_ludwig_prin cipios_filosofia_futuro.pdf.

Feuerbach, L. (2009a). A essência do cristianismo. Tradução de José da Silva Brandão. Petrópolis, RJ: Vozes.

Feuerbach, L. (2009b). Princípios da filosofia do futuro. Recuperado em 06 setembro, 2020, de http://www.lusosofia.net/textos/feuerbach_ludwig_principios_filoso fia_futuro.pdf. 
Feuerbach, L. (2009c). Preleções sobre a essência da religião. Tradução de José da Silva Brandão. Petrópolis, RJ: Vozes.

Krenak, A. (2019). Ideias para adiar o fim do mundo. São Paulo: Companhia das Letras.

Lênin, V. I. (1977). O socialismo e a religião. Recuperado em 17 abril, 2021, de https: //www.marxists.org/portugues/lenin/1905/12/03.htm.

Mariátegui, J. C. (2003). Regionalismo Y Centralismo Recuperado em 12 março, 2021, de https://www.archivochile.com/Ideas_Autores/html/mariategui_jc.html.

Mariátegui, J. C. (2010). Sobre el problema indigena. Recuperado em 12 março, 2021, de https://biblioteca.org.ar/.

Serrão, A.V. (1999). A humanidade da razão: Ludwig Feuerbach e o projeto de uma antropologia integral. Braga: Fundação Calouste Gulbenkian. 